\title{
Were It a New-Made World: Hawthorne, Melville and the Unmasking of America
}

Michael Broek

\section{(2) OpenEdition \\ Journals}

Electronic version

URL: https://journals.openedition.org/ejas/7757

DOI: $10.4000 /$ ejas. 7757

ISSN: 1991-9336

Publisher

European Association for American Studies

Electronic reference

Michael Broek, "Were It a New-Made World: Hawthorne, Melville and the Unmasking of America", European journal of American studies [Online], 5-1 | 2010, document 2, Online since 03 February 2010, connection on 08 July 2021. URL: http://journals.openedition.org/ejas/7757 ; DOI: https://doi.org/ 10.4000/ejas. 7757

This text was automatically generated on 8 July 2021.

Creative Commons License 


\title{
Were It a New-Made World: Hawthorne, Melville and the Unmasking of America
}

\author{
Michael Broek
}

The artist, however faithful to his personal vision of reality, becomes the last champion of the individual mind and sensibility against an intrusive society and an officious state.

- President John F. Kennedy, in 1963, at Amherst College for the dedication of the Robert Frost

Library

In George W. Bush's America, Emerson could not be elected dogcatcher. - Bloom, Best Poems of the English Language

Utilizing Ernest Gellner and Benedict Anderson's definition of "nationalism," this article concerns American nationalism and aesthetics and argues that Hawthorne and Melville were among the first American imaginative writers to challenge the myth of American Exceptionalism in terms of their aesthetic operations, insofar as Hawthorne's sense of ambiguity and Melville's sense of multiple perspectives challenges the validity of any single monological narrative of national identity. The article further places this argument within the context of modern and contemporary American literature, with particular references to Flannery O'Connor and Cormac McCarthy, whose most recent novel, The Road, was released on film in the Fall of 2009.

In America, nationalism and literature have always been inexorably connected, or as Sacvan Bercovitch writes, "[American] culture was committed from the start to what social scientists have termed the process of modernization" (American xii), "modernization" here closely allied with Ernest Gellner's definition of "nationalism," in which the pressures and requirements of industrialization force the political and cultural (or, in this case, literary) units to merge. Of course this is not to say that 
America has always been industrial and never agrarian, but rather that, from John Winthrop forward, America's "founders" professed their faith in the essential homogeneity of American society and culture, a culture by means of which each citizen, properly exercising his or her particular talents, could enjoy the fruits of America's divine ordination - whether those fruits were political, economic, or more likely both. As an allegedly classless society, America had to develop and adhere to a narrative of national identity, a mythology of American Exceptionalism, if it was going to cohere, and this narrative has been developed through the medium of a complex, imagined, "literary" narrative. Indeed, no American writer of imagined literature can escape nationalism's pull, for even when the narrative of national identity seems remote, it exists in the background, arguing in favor of its symbols and tropes.

2 Bercovitch and others, such as A.N. Kaul, Irving Howe, and Richard Slotkin, have certainly commented at length upon American mythology - its religious, political and economic rhetoric and realities - and the relationship of these indices of culture to American literature. ${ }^{1}$ More recently, Susan Faludi, in The Terror Dream: Fear and Fantasy in Post-9/11 America, discusses the mythological underpinnings of America's response to the events of September 11: "The anxieties [9/11] awakened reside deep in our cultural memory. And the myth we deployed to keep those anxieties buried is one we've been constructing for more than three hundred years" (13). What I wish to emphasize is the monological essence of this mythological narrative, its constitution as what Bakhtin calls an "authoritative discourse" which "permits no play with the context framing it" (343), for it is this non-contextuality against which I will argue Herman Melville and Nathaniel Hawthorne were rebelling, though not typically in overtly political terms but in terms of their aesthetic operations.

3 Aesthetically, what Hawthorne and Melville sought was to break open old myths and symbols, many of which had become grounded in the myth of American Exceptionalism, to discover what emerged into the light, what might be found behind the "veil" - the veil being a favorite trope of Hawthorne's. As Melville's Ishmael bobs up from the sea and Hawthorne's Coverdale drops the mask of his self-delusion, as Bartleby's narrator cries "Ah, humanity!" and Pearl quits her mother's settlement, a new metaphor is revealed and an old narrative, grounded in myth and symbol is destroyed. It is this "breaking into blossom," to borrow a line from the American poet James Wright, that challenges the monological myth of national identity, and this challenge emerges as a consequence of rejecting (always tentatively and incompletely) the truth of aloneness - the aloneness of solitude and death, but more importantly in terms of this argument, the aloneness of closed symbols and single-voiced narratives. Thus, an aesthetic operation emerges as an anti-nationalistic political argument, not because it is an aesthetics that concerns itself with America but because it largely does not. The "Un-masking" of this article's title, then, refers to this process of revealing, as the consequence of an aesthetic process, of what lies behind and beyond the self-generated and willingly-imposed "mask" of American national identity.

4 This argument, then, will proceed in three parts. The first will seek to establish the terms of this narrative of American Exceptionalism; the second will suggest how Hawthorne and Melville resist this narrative; and the third will posit the ways in which a number of American authors have continued writing in the same aesthetic vein. Thus, this article will cover a great deal of literary territory and, as such, its outlines, while I hope not fragmentary, are certainly preliminary. This argument reaches beyond 
Hawthorne and Melville to encompass a number of modern and contemporary American authors, but it is my hope that what will be established here are at least the parameters of a worthwhile discussion, particularly as it may be an argument somewhat at odds with current scholarship on these canonical authors, much of which emphasizes the historical, biographical, psychological, and public aspects of these authors' works, to the neglect of how their writing operates in aesthetic terms on the page.

I.

5 Speaking of the poet Robert Frost, President John F. Kennedy says the poet "was supremely two things: an artist and an American." Kennedy's view of the artist as an independent agent is complex, so that he praises the poet as an artist whose "sense of the human tragedy fortified him against self-deception and easy consolation." This view is close to that of the Southern fiction writer Flannery O'Connor, who argues, "The person who aims after art in his work aims after truth in an imaginative sense, no more and no less" (Mystery 65).

6 And yet, in remarks that largely concern the moral necessity of lending service to "the Great Republic," Kennedy cannot help buy ally Frost's exceptionality with the exceptionality of the nation in which he lived. But if all nationalism is a form of mythology, as Gellner suggests, then can Kennedy at once claim that the artist eschews self-deception and embraces or at least embodies the mythology of nationalism? Gellner argues that necessary for the production of the "national" is the perpetuation of a context-free, unitary language, which is concomitant with the myth of "nations as a natural, God-given way of classifying men, as an inherent though long-delayed political destiny" (48). How else to ensure that this new mobile and homogenized population remained relatively placid in the face of economic and political uncertainty? If, according to Gellner, nationalism is "the establishment of an anonymous, impersonal society, with mutually substitutable atomized individuals" (57), then where does this leave American literary writers?

7 Perhaps they may form something like the "Anacharsis Clootz deputation," recounted by Melville, that marched into the French Assembly in 1790 to air "the world's grievances" (Moby-Dick 107). And yet what commonly occurs is that such criticism of the institutions of power, democratic or otherwise, is itself absorbed into the mythology of nationalism or, as Kennedy notes, "In serving his vision of the truth, the artist best serves his nation." Thus social criticism is embraced in America and transformed into a narrative of national identity; thus is Hester Prynne's radicalism often interpreted, by critics such as Bercovitch, as an ultimately conservative capitulation to the sources of national myth; thus is Walt Whitman's rejection of slavery and sexism neutralized.

O'Connor, as well, was encouraged to return the warm embrace offered by an America drunk on its Dream. Responding to a Life magazine editorial that exhorted modern writers to consider the joys of living in America, O'Connor replies rather sarcastically, "[T]here could be some ugly correlation between our unparalleled prosperity and the stridency of these demands for a literature that shows us the joy of life" (30).

Whitman is particularly illustrative of this point. Harold Bloom refers to Whitman, whom he considers the "Center of the American Canon," as an "American religious prophet" and an "American Jesus" (Western Canon 249). Herein Bloom aligns Whitman with the myth of American Exceptionalism. For as the mythology of the "resurrected 
man" - of the underdog, of the heroic "common man" - is such a prevalent American type, then Whitman is that type. But Whitman requires no help from Bloom to claim his national roots, Whitman readily claiming them for himself.

10 This indeed is what separates Whitman from the other two writers whom Bloom also describes as members of the early American canon - Hawthorne and Melville. These two authors apprehended American democracy - American nationalism - in a different light. They had to, if they were to realize their aesthetic potential. Once the artist has to deal with the fact of the nation, then the artist must place himself against this fact. Joyce would not be Joyce without Ireland, Faulkner not Faulkner without the American South. Flannery O'Connor writes, "The first product of self-knowledge is humility, and this is not a virtue conspicuous in any national character" (Mystery 35). Arguably, Whitman claims for himself too much.

11 Naturally then, one understands O'Connor's affinity for Hawthorne who "knew his own problems and perhaps anticipated ours when he said he did not write novels, he wrote romances" (Mystery 38). In other words, O'Connor argues that the writer's allegiance (her allegiance, as well as Hawthorne's) is to a spiritual truth over and above a physical one, to the mysteries of death and grace over and above the logic of symbolism and myth. Thus, in O'Connor's short story "A Good Man Is Hard To Find," the Grandmother is destroyed as she reaches out to touch the Misfit's face, and in Hawthorne's The House of the Seven Gables, Jaffrey Pyncheon sits immobile in the parlor as he quietly chokes on his own blood.

12 The truths that these writers serve are illustrated as a consequence of the individual's struggle against whatever deadens the soul. This sense of one's spiritual bondage as a larger issue than even the physical bondage of chattel slavery is prevalent in Hawthorne's work, and it is the source of some criticism, since writers and thinkers surrounding Hawthorne (and more popular than himself) had made the abolition of Southern slavery such an issue in their work, an issue that he only obliquely addressed. Following Hawthorne's lead, Melville also developed a style in Moby-Dick (famously dedicated to Hawthorne) that was far more concerned with the illumination of enduring human truths than with criticizing contemporary myths of social or national identity, though this interpretation of Melville's work is controversial, and I will take it up more thoroughly in the next Section.

13 Edward Said, in Culture and Imperialism, notes that "American attitudes toward American "greatness," which includes its sense of its own "specialness" and "altruism," have "remained constant" (7). Hawthorne and Melville, however, recognized the falseness of this narrative. Biographer Brenda Wineapple asserts that Hawthorne was always concerned with "national hypocrisy [...] whether he writes about Puritans, Tories, rebels, or transcendentalists," perceiving that "America is conceived in liberty and oppression" (350 emphasis added). His "Chiefly About War Matters," published in the The Atlantic in 1862, offended the magazine's readers, according to Wineapple, "not because it frequently seems pro-Southern but because it is so virulently and unequivocally antiwar - and this during a war fought for such a palpable moral good" (352). "Chiefly About War Matters" skewers the Northern narrative just as much as the Southern, and it even turns on itself, as Hawthorne, adopting the voice of a Northern editor sympathetic to Lincoln, inserts editorial footnotes critical of the author (who is himself). 
14 One hundred and fifty years after its founding in 1857, The Atlantic, where Hawthorne published numerous essays, published "The Future of the American Idea," a compilation of responses by notable Americans to the question, "What is the American Idea?" The Pulitzer-Prize winning essayist George F. Will writes, "Talk about 'the' American idea is dangerous because it often is a precursor to, and an excuse for, the missionary impulse that sleeps lightly, when it sleeps at all, in many Americans" ("Future" 20). The author Joyce Carol Oates remarks simply, "How heartily sick the world has grown, in the first seven years of the 21st Century, of the American idea!" ("Future" 22). Similarly, Hawthorne's narrators implicitly question the "American idea," as in the story "The Gray Champion": "Here [...] were the veterans of King Philip's war, who had burnt villages and slaughtered young and old, with pious fierceness, while the godly souls throughout the land were helping them with prayer" (237). ${ }^{3}$

15 Benedict Anderson, in Imagined Communities, highlights this connection between nationalism and language, and in particular the role of print capitalism, which he argues served to standardize languages and to fix power amongst those who knew the standard dialect:

The coalition between Protestantism and print-capitalism, exploiting cheap popular editions, quickly created large new reading publics [...] and simultaneously mobilized them for politico-religious purposes [while also producing] Europe's first important non-dynastic, non-city states in the Dutch Republic and the Commonwealth of the Puritans (40).

16 Not incidentally, it was in the Dutch Republic where the Pilgrims found relative safety from persecution in England before embarking for America, and it was in the Commonwealth of the Puritans where the Geneva Bible, which included extensive notes on interpretation in the vernacular language, was developed and printed. The Geneva Bible finally entered America via William Bradford and the Plymouth Pilgrims.

17 While Anderson makes the point that a particular standardized print-language is not necessarily associated with a particular nation (English language Britain and English language America are the obvious examples here), the issue is that from the establishment of Plymouth Colony onwards, English - not courtly French or church Latin - was the language of power in America and everyone had access to it.

Language had never been an issue in the American nationalist movements. [...I]t was precisely the sharing with the metropole of a common language (and common religion and common culture) that had made the first national imaginings possible (Anderson 197).

18 That Benjamin Franklin was a printer is not incidental to the development of a particular American identity.

19 Gellner's and Anderson's account of the interrelationship between language, culture, industrialization and nationalism is relevant because it directs us to the point that concomitant with the development of a context-free language - that is, a language and an idiom that is technically standardized and universally understood, but more importantly that serves to mask difference and to manufacture a (false) sense of shared destiny - has been the development of an American national mythology, and it is this mythology against which Hawthorne and Melville were the first strong American 
imaginative writers to place themselves, "un-masking" as it were, the false front of American Exceptionalism.

Thus Mikhail Bakhtin, while not writing specifically about nationalism, suggests what may now seem obvious, that the artist's resistance to a single, monologic narrative is, at least in the American context, inherently anti-nationalistic because, in what he identifies as "artistic prose," the author places narratives against themselves such that this dialogization penetrates from within the very way in which the word conceives its object and its means for expressing itself, reformulating the semantics and syntactical structure of discourse (284).

In other words, the "artistic" author is never satisfied with the unified, homogeneous language handed to him or her by the nation, the single narrative of national identity that serves to mask the complexities and paradoxes of "real" life. Rather, the author finds the fissures within the narrative, extrudes multiple dialogues, often in conflict with each other, and repacks their meaning. If Bakhtin is correct, then, insofar as Hawthorne and Melville, as artists, had to resist the predominant idiom, they had to resist American mythology, since for them it constituted the idiom. Such resistance is the act of un-masking.

II.

In his short story "Earth's Holocaust," Hawthorne describes an enormous bonfire into which all manners of narrative are thrown by those who would purify the world of its worn-out symbols: "badges of knighthood" (887); "perfumed letters" and "a collegegraduate, his diploma" (893); "marriage-certificates" and "bales of paper-money" (897); "the weight of dead men's thought" (898), all "the plague of letters" (901); "priestly garments" (902), and even the Bible, which survives, minus "the finger-marks of human perfection" (904). The only item spared the fire, because it is overlooked, says the narrator, is the human heart, which a jilted lover "would willingly have flung" into the fire, "but could find no means to wrench it out" (893). The heart, "wherein existed the original wrong" cannot be purified, and thus it is fated to repeat the narratives that the impulse to reform had just erased (906).

This "wrong," however, is not simply "original sin," but, as Hawthorne describes in "The New Adam and Eve," it is our every attempt set down "false wisdom" and "specious theories," (761) every attempt to erect a system of ideas, a single and singular narrative, in lieu of acts of human empathy.

24 There is a distinction that may be made between Hawthorne and Melville and other mid-Nineteenth Century writers, a distinction that arises out of aesthetics. What Bercovitch argues about American "classic" writers, namely that "the dream that inspired them to defy the false Americanism of their time compelled them to speak their defiance as keepers of the dream" (American 180), may be most usefully said about the Transcendentalists, and in particular Emerson, Thoreau and Whitman, a point Bercovitch aptly makes (American Epilogue). But Bercovitch also includes in this vein Melville and Hawthorne, in the sense that their invocation of doom and ambiguity, because of its cosmic, millennial, universal flavor (in a sense, because of its monologism), partakes of the same figural tropes as the exceptionalism that it resists. But Bercovitch's argument about these two writers depends on a very particular reading of their work. I believe that the aesthetic operations employed by Hawthorne and Melville, most specifically considering their manipulation of perspective and metaphor, places them in a new category - not seeking to champion the premises of 
American Exceptionalism, and not primarily critical or conservative, either (as Bercovitch argues). Rather, the aesthetic manipulation of perspective and metaphor employed by Hawthorne and Melville opens up the possibility of rendering an experience that is finally outside of nationalism and its mythologies.

Jonathan Arac makes a similar argument in his American Literary Narrative as he argues that Melville and Hawthorne "set their work apart from national narrative" in that they "seemed [...] to transcend and, implicitly, to criticize the world of common life" (4). He draws a distinction between the publication of "national narratives," which he most closely associates, in terms of imagined fiction, with James Fenimore Cooper; "local narratives," which he associates with writers such as Washington Irving and the Southwestern Humorists; and the advent of "literary narratives," such as those, Arac argues, developed by Hawthorne and Melville.

Arac makes a particular argument about Cooper that serves as an interesting point of difference in relation to Hawthorne and Melville: "Cooper's fictions operate as strategies of containment, that is, as imaginary techniques for negotiating the complexities of the life that both he and his readers were living" (11 emphasis added). For example, in Last of the Mohicans, Hawk-eye repeatedly asserts his rugged masculinity in contrast to the effeminate flute-playing of the hapless Puritan minister, David Gamut. Hawk-eye categorically rejects Gamut's view of the universe as "foreordered" and instead asserts that he is the master of his fate (108-109), even as he fulfills the role of knight protector, safekeeping the honor of two white women against the blood-thirsty Iroquois. This sense of the rugged "maverick" as the independent yet noble defender of all things virtuous is a predominant theme of American Exceptionalism.

27 As Arac argues of Mohicans, "National narrative did not permit an alternative history of America in which the most heroic of Indians and the most passionate of mulattoes founded a new line" (12). Evidently, while it is permissible to reject the rigid framework of Puritan belief, it is not possible to subsequently dwell outside of a mytho-symbolic system - this time in the form of the unchallenged assumptions of white, Christian, masculine dominance and chivalric attitudes. Similarly, Bumppo's women must be virginal and white, which is why he must reject Judith's overtures of marriage in The Deerslayer. Such narrow perceptions are never crossed by Bumppo, and in fact he consistently defends their validity. Contrast this figure, however, with the "heroes" (or, rather, anti-heroes) drawn by Hawthorne and Melville. Hawthorne's narrator Miles Coverdale, for example, following his withdrawal from the supposed utopian community of Blithedale, laments, "[...E]verything I meet with, now-a-days, makes me wonder whether I am awake" (155). He no longer knows who he is and thus cannot trust his perceptions. In this sense, he has lost his faith in the clear light of America and, although he has not made any broad political statements, the fact that Coverdale has drawn into question the veracity of any single narrative forms, itself, a criticism of the myths of national exceptionalism.

But this is not to say that Bumppo's pronouncements should be confused with Cooper's aesthetic operations, a distinction that Arac may too quickly dismiss. Certainly, even when Bumppo criticizes American settlers, as for example when he notes the wasteful, short-sighted attitudes of the pigeon shooters in The Pioneers, he does not ever enter into a reflective dialogue with himself. Bumppo consistently epitomizes a single point of view, one that comes to represent the typical "common man": strong-willed but 
charitable, moral but secular, independent but faithful, industrious but realistic, and in the case of Harvey Birch in Cooper's The Spy, unrelentingly patriotic.

But this is primarily Bumppo's narrative frame, not necessarily the argument suggested by Cooper, who in fact seems sympathetic to his protagonist's position as a victim of the American frontier's voracious appetite for land, resources, and control. ${ }^{4}$

As the "unitary language," or monologism, posited by Gellner has as a part of its syntax the patterns of allegorical language and symbolism that constitute the nation's sense of itself, then in Hawthorne's The Blithedale Romance, Coverdale's act of narration has as its consequence the splitting of this language into numerous conflicted and conflicting perspectives. In other words, as Coverdale satirizes himself, recognizing his own acts of self-deception, then his jibs and jabs at "truth," always contingent and always selflimiting, call into question all attempts to frame any single narrative.

31 It is obvious that the IDEA of "America" and its religious, political and economic rhetoric and realities serve as Hawthorne's touchstones in Blithedale, but this is only ancillary to the full argument of the novel, which is rendered in aesthetic terms. Insofar as Coverdale recognizes his aloneness and yet struggles against this recognition, as he recognizes in himself the "Veiled Lady" and seeks, albeit haltingly, to "unveil" himself, then he strives toward his own un-masking, which is always politically agitating and anti-nationalistic because it only emerges as a consequence of the recognition of the inadequacy of the "unitary language" and the adoption instead of a polyphonic, heterogeneous language discourse, or more simply, the adoption of a new way of seeing. Ethan Brand, in Hawthorne's short-story of the same name, throws himself into the fire because he discovers that his insistence upon a single question is entirely incompatible with the complexities of experience. For him, the havoc he has wreaked cannot be undone. Similarly, Coverdale becomes aware of what he has done and not done that has resulted in the destruction of his community and his friends and lovers. Anderson, in Imagined Communities, points out what may seem an obvious fact on its surface: '[...P]ersonhood, identity [...] because it cannot be 'remembered,' must be narrated" (204). Coverdale takes that step, he narrates himself, and so perhaps discovers that he belongs to no community at all. In this way, through its aesthetic operations - in this case Hawthorne's manipulation of the novel's point of view - the novel challenges the myth of American Exceptionalism, and in this way Coverale's "failure" may be conceived of as only a prelude to a struggle that could lead to his eventual success - the discovery of a new way of knowing outside of the national narrative.

Hawthorne's much more canonical The Scarlet Letter, as well as Melville's Moby-Dick have achieved their status, I would argue, because they avoid direct confrontation with the crucial political issues of the day, such as slavery, expansionism, and women's rights. The Scarlet Letter and Moby-Dick are set, respectively, at the date of America's earliest origins and as far away from American shores as possible. Hawthorne's Blithedale, and Melville's commercially successful (because exotic) but less canonical Typee and Omoo overtly criticize American Exceptionalism - its utopian movements and its missionary zeal - but these novels have largely survived because of their author's strong aesthetic successes in their other works. ${ }^{5}$ In fact, in White-Jacket, Melville's novel just prior to Moby-Dick, the author makes one last appeal to American Exceptionalism, an appeal that Bercovitch points to as evidence of the power of "America" as symbol and promise in Melville's work. It is a jarring passage to which Bercovitch points 
because, while it is particularly jingoistic, it seems particularly out of place in a narrative that is highly critical of monological thinking.

However, Arac makes an interesting observation, which is that while Hawthorne and Melville seek for themselves an "imaginary" space outside of politics, they nevertheless generate their most notable works during a period immediately prior to the Civil War, amid great public consternation and argument over the fate of the Republic. It could be argued that, while their novels do not directly confront, as does for example Stowe's Uncle Tom's Cabin, the issue of slavery and national unity, they nevertheless are inspired by the conflict of perceptions raging around them at the time of their writing. Indeed, by the time of Moby-Dick, almost all traces of an appeal to American Exceptionalism have vanished in Melville, "America" as symbol, instead, sinking literally and figuratively to the bottom of the Pacific.

Melville, of course, explores the collusion of theocracy, autocracy and the consequences of despotism in Moby-Dick, and Ishmael seems to conclude that neither acquiescence - as embodied by Starbuck - nor outright rebellion against the world- as attempted by Ahab - will ultimately yield any positive result. And in Pierre, as biographer Andrew Delbanco argues, "Melville curses sentimental culture for refusing to recognize that its standards and practices are arbitrary and its collective memory as entranced by myth as that of distant savages" (205 emphasis added). Indeed, Delbanco finds ample political subterfuge in Moby-Dick, but these references are indirect and even arguable, such as Delbanco's effort to draw a parallel between Captain Ahab and the Southern orator and pro-slavery political figure John C. Calhoun, but such is the state of criticism that emphasizes history and culture rather than aesthetics. ${ }^{6}$

However, Bercovitch portrays Melville himself as a purveyor of myth in that he "could not envision a different set of ideals - an antinomian self-sufficiency, a non-American course of progress - beyond that which his culture imposed" (Jeremiad 193). He finds that Ahab's monomania and destruction implicitly "argue the need for the containment of individualism" (Jeremiad 192). In other words, Moby-Dick remains complicit with the myth of American Exceptionalism because it offers no viable alternative. But while this may be true of Pierre, which implodes upon on its own satire, it is not, I believe, true of Moby-Dick.

Rather, Ishmael - an outcast and a survivor - lives out of sight of the "American wood" of the ship's construction (MD 426) which, like the Birnam wood of the witches' prophecy, is but a false front, concealing truth, in this case the truth as it is symbolized by Pip, who is screwed to the Pequod's bowels. The singularly un-Christian and hence putatively un-American Ishmael - Abraham's dismissed son - survives Ahab's madness, and thus his survival suggests that some "post-American" world is possible.

The characters imagined by Hawthorne and Melville come to terms with their aloneness - whether this aloneness takes the form of a physical separation or isolation, or a spiritual and psychological one - while rejecting themselves as exceptional. Hester finally lives her life outside of the symbol system that has condemned her, transforming her "A" into "Able," but Dimmesdale, who as a Puritan minister is a representative of all that is exceptional, is dead. He cannot transcend the monologism that is his inheritance. Ahab's isolation and his allegiance to his single-minded perception nearly doom Ishmael. 

(in White-Jacket), or specific human weaknesses, such as greed and selfishness (as in The Blithedale Romance), they always temper their observations with a simultaneous argument, rendered in aesthetic terms, that any sort of monologism, even of the sort that promises charity and loving-kindness, is ultimately anathema to human growth and development. "There are no new truths," laments Zenobia (Blithedale 206). Thus, the ultimate target of their cultural criticism is the single-voice narrative, a national narrative that, in America at least, speaks to every facet of the individual's life.

It is true that Melville does sing America's praises in nearly millennial terms in WhiteJacket: "And we Americans are the peculiar chosen people - the Israel of our time; we bear the ark of the liberties of the world" (151). However, he also blasts the singleminded pomposity of the ship's captain, the injustice of flogging, and the absurdity of praying aboard a warship:

[A] man-of-war is but this old-fashioned world of ours afloat, full of all manner of characters - full of strange contradictions; and though boasting some fine fellows here and there, yet, upon the whole, charged to the combings of her hatchways with the spirit of Belial and all unrighteousness (390 emphasis added).

These themes, however, do not fully reflect the novel's concerns, though Bercovitch highlights the passage about the "chosen people" in his argument relating Melville to his thesis in The American Jeremiad. Rather, what emerges from the conclusion of WhiteJacket is the narrator's abandonment of the aptly named United States, and although the abandonment is accidental, resulting from his fall from the yard-arm, it results in his metaphoric rebirth:

A bloody film was before my eyes, through which ghost-like, passed and repassed my father, mother, and sisters. [...] For one instant an agonizing revulsion came over me as I found myself utterly sinking. [...] I was conscious of a feeling like being pinioned in a feather-bed, and, moving my hands, felt my jacket puffed out above my tight girdle with water. [...] I whipped out my knife [...] and ripped my jacket straight up and down, as if I were ripping open myself. With a violent struggle I then burst out of it, and was free (394-95). Thus, Melville turns aside from the polemical language he had earlier employed in favor of a moment of transformation and the adoption of a new perspective, a perspective that would be further problematized in Moby-Dick.

In the short story "Wakefield," Hawthorne writes: "Amid the seeming confusion of our mysterious world, individuals are so nicely adjusted to a system, and systems to one another, and to a whole, that, by stepping aside for a moment, a man exposes himself to a fearful risk of losing his place forever" (298). Yet it is only through the experience of this loss of one's "place," both Hawthorne and Melville suggest, that one may hope to find oneself, even if, as for Ahab, that experience results in madness and death. III.

In The Confidence Man: His Masquerade, written at the end of Melville's novel-writing career, the merchant, faced with the challenge of the "unfortunate man," opines excitedly:

Ah, wine is good, and confidence is good; but can wine or confidence percolate down through all the stony strata of hard considerations, and drop warmly and ruddily into the cold cave of truth? Truth will not be comforted. Led by dear charity, 
lured by sweet hope, fond fancy essays this feat; but in vain; mere dreams and ideals, they explode in your hand, leaving naught but the scorching behind! (73)

Herein, Melville summarizes the themes both he and Hawthorne had been addressing for a decade, from about 1850-1860, across all their major novels. The merchant's wine is not enough to forestall the "scorching" of truth; and confidence, or faith in systems and symbols, cannot assuage its difficulties. For Melville, as for Hawthorne, this truth was nothing less than the fact that "the natural heart" had been "authoritatively admonished" (Confidence Man 73).

I would finally like to suggest that the merchant's outburst in The Confidence Man reflects an attitude that is prevalent and powerful across much of modern American literature. It may be illuminating to apply the mode of aesthetic consideration of literary texts that I have outlined to a wide range of works, a few having direct connections to Hawthorne and Melville, but most having none, allied only in the sense of their discoveries and their manner of aesthetic operations.

Ernest Hemingway, writing in A Moveable Feast about his creative process, says, "I was learning something from the painting of Cézanne that made writing simple true sentences far from enough to make the stories have the dimensions that I was trying to put in them" (13). I find this a rather astonishing statement, considering that Hemingway, as an ambulance driver, had just witnessed the horrors of trench warfare and yet was turning to Impressionist painting to find something missing in the act of simple observation, but there must have been something in Cézanne's work that hinted at more than simple "representation."

It is no mistake that "Modern" American writers find their permissions and inspiration in the "Romantic" authors of 100 years previous, or in "Impressionist" artists of roughly the same period. O'Connor cites Hawthorne. Faulkner cites Melville. Wallace Stevens, in his essay "The Relations Between Poetry and Painting," writes, "Poetry and painting alike create through composition" (163), which he argues is an effort of mind, a "labor of calculation," and produces "deliciae of the spirit as distinguished from delectationes of the senses" (166). Or, as O'Connor writes more simply, “'You can't say Cézanne painted apples on a tablecloth and have said what Cézanne painted' " (qtd. in Mystery 75). according to Hawthorne "while it sins unpardonably, so far as it may swerve aside from the truth of the human heart - has fairly a right to present that truth under circumstances [...] of the writer's own choosing or creation" (House Preface 1); or as Melville writes in Mardi, "Some revelations show best in twilight" (716). O'Connor writes, "The artist penetrates the concrete world in order to find at its depths the image of its source, the image of ultimate reality" (Mystery 157). This may have been the revelation that Hemingway was searching for in Cézanne, that is "the truth of the human heart," which Henry arguably experiences at the conclusion of A Farewell To Arms.

Cormac McCarthy's No Country For Old Men, for example, explores the same sense of violence and powerlessness found in Moby-Dick and The House of the Seven Gables. Sheriff Bell, facing a malevolence that he cannot subdue, quits his position and confesses his cowardice to his father, while the ultra-violent Chigurh professes a kind of absolute faith in destiny and in himself as a tool of fate. Bell says at the novel's end, 
I'm bein asked to stand for something that I don't have the same belief in as I once did. Asked to believe in something I might not hold with the way I once did. [...] I've been forced to look at it again and I've been forced to look at myself. For better or worse I do not know (296).

In the same way that Hepzibah is forced to consider her withered reflection, Sheriff Bell has lost his faith in himself and his society. Chigurh, conversely, experiences no crisis of faith because, as he explains to the woman he is about to murder, "A person's path through the world seldom changes and even more seldom will it change abruptly" (259). His belief is Calvinistic, and it enables him to disassociate himself from the consequences of his actions upon others. He cannot swerve from his fate or, as he explains, permit others (notably his victims) to swerve from theirs.

51 In this sense, Chigurh is an Ahab. The lines on Ahab's chart are etched on his forehead, his soul is "laid with iron rails" (Melville MD 143), just as Chigurh explains, "All followed to this. The accounting is scrupulous. The shape is drawn. No line can be erased" (259). Chigurh's world is amoral because there are no choices to be made and hence no guilt or remorse, though also no possibility of joy.

Ahab, however, never ceases to recognize the paradoxical relationship between joy and grief, as he attests when he looks in Starbuck's eyes, while Chigurh's psychic wounding yields a different result, more akin to the attitude of The Misfit in O'Connor's "A Good Man Is Hard To Find," whose murder spree is also ruthless, unyielding, and seemingly motivated by a similar philosophy of fate. The Misfit's creed, "No pleasure but meanness," (152) is founded upon his recognition of an amoral world, a recognition prompted by the circumstances of his fate (the mystery of his incarceration and his father's death) and his inability to "touch" anything divine. In fact, it is the Grandmother's attempt to literally touch The Misfit that directly results in her murder. This is the moment, as O'Connor describes it, that the Grandmother "realizes, even in her limited way, that she is responsible for the man before her and joined to him by ties of kinship which have their roots deep in the mystery" (Mystery 112).

But while The Misfit recognizes that "goodness" is at least possible, ironically remarking that the Grandmother could have been good "if it had been somebody there to shoot her every minute of her life" (153), Chigurh only believes in the "coin toss"life and death as matters of simple chance.

Sheriff Bell, then, is similar to the Grandmother in that he too undergoes a transformation as he faces the ruthlessness of Chigurh. His encounter with what he suggests is "the devil" challenges what he had believed about himself and his community, and at the novel's conclusion he attempts to "save" the "Mexican," whom he believes has been wrongly prosecuted. The Mexican's response, however, like The Misfit's, is ruthless.

This sense of one's perceptions as always contingent and liable to cancellation or revision by a stronger "Other" is at the heart of the conflicts illuminated by Hawthorne and Melville. As Coverdale cannot "see" the Veiled Lady, as Bartleby goes blind, as Hepzibah squints and as the " $\mathrm{A}$ " is a symbol that resists transformation, as The Misfit cannot read the papers that explain why he is imprisoned and as Bell confesses that the narrative of his "heroic" actions in Vietnam is false, what is revealed is the "truth" that no story, symbol system, or faith is ever entire or sufficient. 
56 President Kennedy, like all proponents of American nationalism, may wish to claim the artist as a citizen of the Great Republic, but these citizens, at least in the case of Hawthorne and Melville, are more likely to echo the views of Hester Prynne:

For years past she had looked from this estranged point of view at human institutions; and whatever priests or legislators had cherished; criticizing all with hardly more reverence than the Indian would feel for the clerical band, the judicial robe, the pillory, the gallows, the fireside, or the church. The tendency of her fate and fortunes had been to set her free (The Scarlet Letter 128).

Sheriff Bell is as much a victim as Hester of "the blackest shade of Puritanism" (Hawthorne Scarlet Letter 147) inasmuch as he withers under the unrelenting gaze of perceptions that he does not understand. It may even be worse for Bell, who suffers as a consequence of his shame and guilt but is afforded no means of expatiation.

58 The similar titles of No Country For Old Men and "A Good Man Is Hard To Find," both of which suggest the emptiness of men's lives, speak to the similar concerns of the two pieces - the possibility of goodness in a violent world, the collision of fate and choice, the accounting of one's soul. Their responses to these concerns are also similar, and these works succeed aesthetically because they allow for what O'Connor refers to as the "literal" (Mystery 113) resolution of each character's struggle, by which she means that the writer has remained faithful to a deeper truth and avoided sentimentality.

59 In McCarthy's The Road, however, the resolution does not arise naturally from the circumstances of the novel. This is illustrated, for example, by each novel's different handling of the metaphor of "the fire." No Country ends with Bell's dream of his father carrying the fire out into the wilderness and away from Bell:

Never said nothin. He just rode on past and he had this blanket wrapped around him and he had his head down and when he rode past I seen he was carryin fire in a horn the way people used to do and I could see the horn from the light inside of it. [...A]nd I knew that whenever I got there he would be there. An then I woke up (309).

But whereas Bell experiences a disconnection from the father and from the past, in The Road, the son explicitly receives "the fire" from the father and is reborn into innocence.

61 In a sense, the boy in The Road is a Billy Budd, painfully one-sided and almost impossibly innocent, for whom "to deal in double meanings and insinuations of any sort [is] quite foreign to his nature" (Melville, "Billy" 454). Billy Budd is as simple as the prelapsarian Adam, the narrator warns (457), just as the "son" of McCarthy's novel appears destined to become the progenitor of a new, more spiritual, more loving race of human beings. Melville's narrator, however, specifically warns against viewing the boyish Budd as "a conventional hero," noting his stutter, which is particularly evident during moments of high emotion (458), whereas the boy of McCarthy's novel is only pure love, cleaving to his father, then cleaving to his "second" mother, who, it seems, keeps her faith in God and thus does not despair. Budd may similarly cleave to his adopted father, Captain Vere, but the narrator's point of view - his insinuations and satire - seems to purposefully problematize any single reading of Budd's death, whereas the points of view presented in The Road are consistently simplified, described in terms of us and them, good and bad, black and white.

62 In this sense, The Road may be said to belong to that aesthetic tradition that flows out of Cooper and Stowe and their Puritan antecedents, such as Cotton Mather and John Winthrop, an aesthetic that fully confirms the myth of American Exceptionalism in terms of its monological, single-voiced perspective. Even the final chapter of The Road, 
which exhorts the great "mystery" of the universe (241), could be said to confirm the myth, just as Bercovitch has argued that Whitman and the Transcendentalists reconfirmed the myth, in terms of their co-mingling of the universal and the divine with the American. By contrast, Melville's narrator in White-Jacket, as opposed to McCarthy's narrator in The Road, intones: "There are no mysteries out of ourselves" (398). Melville clearly locates the locus of conflict within the self, not in a relationship to a Transcendental "Other." In this way, Melville contradicts the Transcendentalists and those contemporary American authors searching for some answer to madness outside of the limits of human knowing.

Ishmael muses, " 'It maketh a marvelous difference, whether thou lookest out at it from a glass window where the frost is all on the outside, or whether thou observest it from that sashless window, where the frost is on both sides [...] " (Moby-Dick 25). Insofar as the frost is on both sides for Hawthorne, Melville, and those American writers after them who share the same aesthetic sense, then there is no single, clear point of view. This is the mind that views the smoky painting hanging in the Spouter Inn from numerous points of view, drawing metaphors from each. It is the mind that turns to Cézanne's "impressions" in the effort to write what is true. Paradoxically, then, because the aesthetic sensibility that animates these novels operates outside of the myth of American Exceptionalism, in effect "un-masking" the single-voiced narrative and its claims of authority, these works actually emerge as strong opponents of the nationalist impulse, even as they often seem to be saying nothing specific about America itself.

\section{BIBLIOGRAPHY}

Anderson, Benedict. Imagined Communities: Reflections on the Origin and Spread of Nationalism. 2nd ed. London: Verso, 1991.

Arac, Jonathan. The Emergence of American Literary Narrative: 1820-1860. Cambridge, MA: Harvard UP, 2005.

Bakhtin, M.M. "Discourse in the Novel.” The Dialogic Imagination: Four Essays. Trans. Caryl Emerson and Michael Holquist. Ed. Michael Holquist. Austin, TX: University of Texas Press, 1981. 259-422.

Bercovitch, Sacvan. The American Jeremiad. Madison: University of Wisconsin, 1978.

---. The Puritan Origins of the American Self. New Haven: Yale UP, 1975.

Bloom, Harold. The Best Poems of the English Language: From Chaucer Through Robert Frost. New York: Harper, 2004.

---. The Western Cannon: The Books and School of the Ages. New York: Riverhead, 1994.

Cooper, James Fenimore. The Deerslayer, or The First War-Path. New York: Modern Library, 2002.

---. The Last of the Mohicans. New York: Modern Library, 2001.

---. The Pioneers. New York: Penguin, 1988. 
Davie, Donald. “The Legacy of Fenimore Cooper.” Two Ways Out of Whitman. Manchester, England: Carcanet, 2000. 14-26.

Dekker, George. James Fenimore Cooper: The American Scott. London: Routledge and Kegan Paul, 1967.

Delbanco, Andrew. Melville: His World and Work. New York: Vintage, 2005.

Faludi, Susan. The Terror Dream: Fear and Fantasy in Post 9/11 America. New York: Holt, 2007.

"The Future of the American Idea." The Atlantic. Nov. 2007: 13-62.

Gellner, Ernest. Nations and Nationalism. Ithaca, N.Y.: Cornell UP: 1983.

Hawthorne, Nathaniel. The Blithedale Romance. New York: Penguin, 1986.

---. “Chiefly About War Matters.” The Atlantic Monthly. 10.57 (July 1862): 43-61. 3 March 09.

<http://www.theatlantic.com/issues/1862jul/hawthorne.htm>

---. “Earth's Holocaust.” Tales and Sketches. Ed. Roy Harvey Pearce. New York: Library of America, 1982. 887-906.

---. "The New Adam and Eve." Tales and Sketches. Ed. Roy Harvey Pearce. New York: Library of America, 1982. 746-63.

---. “The Gray Champion.” Tales and Sketches. Ed. Roy Harvey Pearce. New York: Library of America, 1982. 236-243.

---. The House of the Seven Gables. Ed. Michael Davitt Bell. Oxford: Oxford UP, 1998.

---. Preface. The House of the Seven Gables. Oxford: Oxford UP, 1998. 1-3.

---. “Wakefield." Tales and Sketches. Ed. Roy Harvey Pearce. New York: Library of America, 1982. 290-98.

Hemingway, Ernest. A Moveable Feast. New York: Scribners, 1964.

Howe, Irving. Politics and the Novel. New York: Horizon, 1957.

Kaul, A.N. The American Vision: Actual and Ideal Society in Nineteenth-Century Fiction. New Haven: Yale UP, 1963.

Kennedy, John F. "Remarks at Amherst College.” Historical Resources. 26 Oct. 1963. John F. Kennedy Presidential Library. 1 Jan. 2008. <http://www.jfklibrary.org/Historical+Resources/ Archives/

Reference+Desk/Speeches/JFK/003POF03Amherst10261963.htm>

Levine, Robert. "Sympathy and Reform in The Blithedale Romance." The Cambridge Companion to Nathaniel Hawthorne. Ed. Richard Millington. Cambridge: Cambridge UP, 2004. 207-29.

McCarthy, Cormac. The Road. New York: Knopf, 2006.

---. No Country For Old Men. New York: Knopf, 2005.

Melville, Herman. "Bartleby, the Scrivener: A Story of Wall Street.” Melville's Short Novels. Ed. Dan McCall. Norton Critical Edition. New York: Norton, 2002. 3-34.

---. “Billy Budd, Sailor: An Inside Narrative.” Tales, Poems, and Other Writings. Ed. John Bryant. New York: Modern Library, 2002. 449-521

---. The Confidence Man: His Masquerade. Ed. Hershel Parker and Mark Niemeyer. Norton Critical Edition. 2nd ed. New York: Norton, 2006. 
---. Moby-Dick. Eds. Hershel Parker and Harrison Hayford. Norton Critical Edition. 2nd ed. New York: Norton, 2002.

---. Pierre, or The Ambiguities. Ed. Hershel Parker. The Kraken Edition. New York: Harper, 1995.

---. Typee, Omoo, Mardi. New York: Library of America, 1982.

---. White-Jacket or the World in a Man-Of-War. Evanston, IL: Northwestern UP, 2000.

O'Connor, Flannery. Mystery and Manners: Occasional Prose. Ed. Sally and Robert Fitzgerald. New York: Farrar, 1970.

---. “A Good Man Is Hard to Find." Collected Works. New York: Library of America, 1988. 137-53.

Said, Edward. Culture and Imperialism. London: Vintage, 1994.

Slotkin, Richard. Regeneration Through Violence: The Mythology of the American Frontier, 1600-1860. Middletown, CT: Wesleyan UP, 1973.

Wineapple, Brenda. Hawthorne: A Life. New York: Knopf, 2003.

\section{NOTES}

1. See A.N. Kaul, The American Vision, Irving Howe, Politics and the Novel and Richard Slotkin, Regeneration Through Violence.

2. All quotes from Melville are drawn from texts that utilize the authoritative Northwestern-Newberry Edition of the Northwestern University Press of the works of Herman Melville.

3. All quotes from Hawthorne (except "Chiefly About War Matters") are drawn from texts that utilize the Centenary Edition of the Works of Nathaniel Hawthorne of the Ohio State University Press.

4. Donald Davie and George Dekker have both written perceptive accounts of Cooper's work that emphasize the aesthetic success of the author's novels, despite their obvious drawbacks.

5. Many critics have written about The Blithedale Romance and its relationship to American Exceptionalism, but not in terms of its aesthetic operations, as I am arguing. See Kaul, for example, or more recently, Robert Levine, "Sympathy and Reform in The Blithedale Romance". 6. See Chapter 6 in Andrew Delbanco's Melville: His World and Work (149-75).

7. McCarthy's novel was transformed into an Oscar winning film of the same title in 2007 (Dirs. Ethan and Joel Coen).

\section{ABSTRACTS}

Utilizing Ernest Gellner and Benedict Anderson's definition of "nationalism," this article concerns American nationalism and aesthetics and argues that Hawthorne and Melville were 
among the first American imaginative writers to challenge the myth of American Exceptionalism in terms of their aesthetic operations, insofar as Hawthorne's sense of ambiguity and Melville's sense of multiple perspectives challenges the validity of any single monological narrative of national identity. The article further places this argument within the context of modern and contemporary American literature, with particular references to Flannery O'Connor and Cormac McCarthy, whose most recent novel, The Road, was released on film in the Fall of 2009.

\section{INDEX}

Keywords: aesthetics, Nationalism, American Exceptionalism, Herman Melville, Nathaniel Hawthorne, Ernest Gellner, Flannery O\&\#39, Connor, Cormac McCarthy.

\section{AUTHOR}

MICHAEL BROEK

University of Essex (UK)- Brookdale Community College (NJ, USA) 